\title{
Physical and chemical properties of wami tilapia skin gelatin
}

\author{
Alexandre da Trindade ALFARO ${ }^{1 *}$, Gustavo Graciano FONSECA², \\ Evellin BALBINOT ${ }^{1}$, Alessandra MACHADO $^{1}$, Carlos PRENTICE ${ }^{3}$
}

\begin{abstract}
Gelatin was extracted from the skin of tilapia (Oreochromis urolepis hornorum) and characterized according to its physical and chemical properties. It had $\mathrm{pH} 4.66$, which is slightly higher than the values reported for gelatins processed by acid solubilization. In general, the ionic content was low, and the average yield of the process was $5.10 \mathrm{~g} / 100 \mathrm{~g}$. The proximal composition of the gelatin was similar to that of the commercial gelatins, with slightly higher moisture content. The tilapia skin gelatin had whitishyellow color and average turbidity of 67 NTU.
\end{abstract}

Keywords: fish gelatin; skin; Oreochromis urolepis hornorum; properties.

\section{Introduction}

Traditionally, collagen extraction for gelatin production is carried out using bones and skins of mammals, mainly of bovines and swines, as raw materials. However, sanitary problems associated with bovine diseases, such as bovine spongiform encephalopathy (MUYONGA; COLE; DUODU, 2004), and restrictions to mammalian gelatin in countries where Islamic and Judaic religions predominate and which only accept such products if they were manufactured according to the religious guidelines (GUDMUNDSSON; HAFSTEINSSON, 1997; JAMILAH; HARVINDER, 2002), have aroused increasing interest in fish gelatins.

Substantial amounts of by-products containing high collagen content are generated during fish processing, and they can be used in gelatin production. Gelatin is obtained from collagen by heating it above the helix-coil transition temperature (triple helix structure) causing the collapse of the structure. These collagen structural changes occur in a relatively narrow temperature range, at which, firstly, the helical structure of the collagen molecule the collapses, and then the unrolling of the molecular chains leads to the slow molecular weight decrease (JOHNS; COURTS, 1977). Since it is derived from collagen hydrolysis and its properties and gelling capacity involve the partial renaturation and denaturation of molecules, its characteristics are mainly dependent on the collagen used (JOHNSTON-BANKS, 1990).

Gelatin quality for a particular application depends largely on its rheological properties (GUDMUNDSSON; HAFSTEINSSON, 1997). However, basic aspects from its physicochemical properties such as composition parameters, solubility, transparency, odor, and taste are attributes that define the overall commercial quality of a gelatin (GÓMEZGUILLÉN et al., 2011). Therefore, the focus of this investigation was to extract gelatin from the skin of wami tilapia and study its physicochemical properties.

\section{Materials and methods}

\subsection{Raw material and chemicals}

Fresh skins of filleted wami tilapia (Oreochromis urolepis hornorum) with estimated average weight of $700 \pm 100 \mathrm{~g}$ were obtained from a company located in the municipality of Pato Branco, PR, Brazil. The skins were stored at $-18{ }^{\circ} \mathrm{C}$ until use (approximately 24 hours later).

Sulfuric acid, sodium hydroxide, and citric acid were obtained from Merck, São Paulo, SP, Brazil. Sodium chloride was purchased from Synth, São Paulo, SP, Brazil. All reagents used were of analytical grade (P.A.).

\subsection{Methods}

\section{Pre-treatment and gelatin extraction}

Gelatin extraction was carried out according to parameters previously defined and established elsewhere (ALFARO et al., 2009). The skins were washed in running water to remove the material adhered to surface of the fish skin and cut in segments of approximately $4 \mathrm{~cm} \times 4 \mathrm{~cm}$. Next, the material was immersed in $\mathrm{NaCl} 0.2 \%(\mathrm{w} / \mathrm{v})$ solution for 5 minutes under continuous stirring to remove non collagenous proteins and pigments. The cut and washed skins were alkali treated $(1: 10 \mathrm{w} / \mathrm{v})$ in a $0.3 \%$ $(\mathrm{w} / \mathrm{v}) \mathrm{NaOH}$ solution. The skins were then washed with running water to remove excess alkali until reach $\mathrm{pH}$ above 8.0. After that, the skins were acid treated $(1: 10 \mathrm{w} / \mathrm{v})$ in $0.3 \%(\mathrm{w} / \mathrm{v}) \mathrm{H}_{2} \mathrm{SO}_{4}$ solution and washed with running water until the $\mathrm{pH}$ was close to neutrality. The skins were then submitted to a second acid treatment $(1: 10 \mathrm{w} / \mathrm{v})$ with a $0.7 \%(\mathrm{w} / \mathrm{v})$ citric acid solution and washed with running water until the $\mathrm{pH}$ was close to neutrality. The extraction was performed in a BIOSTAT B bioreactor (B. Braun Biotech International, Germany) in deionized water for $6 \mathrm{~h}$ at $45^{\circ} \mathrm{C}$. The ratio of $2 \mathrm{ml}$ of solution for $1 \mathrm{~g}$ of skin was kept.

\footnotetext{
Received 20/6/2013

Accepted 3/7/2013 (006087)

${ }^{1}$ Laboratory of Food Technology, Faculty of Engineering, Federal Technological University of Paraná - UTFPR, Linha Santa Bárbara, s/n, CP 135, CEP 85601-970, Francisco Beltrão, PR, Brazil, e-mail: alexandre@utfpr.edu.br

${ }^{2}$ Laboratory of Bioengineering, Faculty of Engineering, Federal University of Grande Dourados - UFGD, Dourados, MS, Brazil

${ }^{3}$ Laboratory of Food Technology, School of Chemistry and Food, Federal University of Rio Grande - UFRG, Rio Grande, RS, Brazil

${ }^{*}$ Corresponding author
} 
After the extraction, the material was filtered in a Büchner funnel through a grade no. 4 Whatman filter paper and dried in lyophilizer-LH series (Terroni Scientific Equipment, São Carlos, SP, Brazil). Next, the gelatin was milled using an analytical millQ298A (SP Labor Equipment Laboratories, Presidente Prudente, SP, Brazil) and hermetically stored in plastic containers at ambient temperature.

\section{Proximal composition of raw material and gelatin}

Analysis for moisture (gravimetry), ash (organic composites incineration), lipids (Soxhlet), and crude protein (Kjeldahl) were carried out according to the following AOAC (ASSOCIATION..., 2000) methods 934.01, 942.05, 920.39, and 984.13, respectively. Protein was determined using a conversion factor of 5.4 for raw material and 5.5 for gelatin (LEACH; EASTOE, 1977).

\section{Minerals}

Eight elements $\left(\mathrm{Na}^{+}, \mathrm{K}^{+}, \mathrm{Ca}^{2+}, \mathrm{Li}+, \mathrm{Fe}^{3+}, \mathrm{Cu}^{2+}, \mathrm{Zn}^{2+}\right.$, and $\mathrm{Mn}^{2+}$ ) were analyzed using cathodic lamps in an atomic absorption spectrophotometer, model Avanta (GBC Scientific Equipment, Hampshire, IL, USA). Readings of the liquid samples were carried out using molecular dissociation in flame and acetylene gas. Standard curves were prepared for the absorption of two different concentrations. Gelatin solutions, $10 \%(\mathrm{w} / \mathrm{v})$ and $1 \%(\mathrm{w} / \mathrm{v})$, were prepared before the analysis by dissolving the solutions in distilled water at $60^{\circ} \mathrm{C}$ under constant agitation for 30 minutes.

\section{Yield}

The yield of gelatin extraction was calculated according to Equation 1 (ALFARO et al., 2009):

Yield $=\frac{\text { Dryweight } \text { gelatin }}{\text { Wet weight } \text { skin }} \times 100$

\section{Color and turbidity}

The color of the gelatin gels $(6.67 \% \mathrm{w} / \mathrm{v})$ was measured using a Konica-Minolta CR-300 chroma meter and reported by the CIE system. $L^{*}, a^{*}$, and $b^{\star}$ parameters indicate lightness, redness/greenness, and yellowness/blueness, respectively. The gels were prepared by dissolving dry gelatin in distilled water at $60{ }^{\circ} \mathrm{C}$, which was kept under constant mechanical shaking for 30 minutes, followed by $18 \pm 1$ hour of maturation at $7^{\circ} \mathrm{C}$.

The turbidity of the gelatin sample was measured at ambient temperature according to the method described by Cole and Roberts (1996) using a Quimis turbidimeter (model Q -179P - TURB, Diadema, SP, Brazil) immediately after sample preparation.

$$
p H
$$

The $\mathrm{pH}$ of the gelatin sample was determined according to the British Standard Institution (1975) method. A 1\% (w/v) gelatin solution was prepared in distilled water at $60^{\circ} \mathrm{C}$, kept at constant mechanical shaking for 30 minutes, and then cooled to room temperature $\left(\sim 25^{\circ} \mathrm{C}\right)$. A pH meter (Analion PM 608, Ribeirão Preto, SP, Brazil) was used for determining the $\mathrm{pH}$.

\section{Statistical analysis}

Data were subjected to analysis as mean \pm SD of triplicate determinations.

\section{Results and discussion}

\subsection{Proximal composition}

It is Known that the functional properties of gelatin depend on the processing parameters (temperature, time, and $\mathrm{pH}$ ), the pretreatment, and the properties and preservation method of the starting raw material (KARIN; BHAT, 2009; ALFARO; FONSECA; PRENTICE, 2012). Therefore, the characteristics of the raw material are decisive for the functional properties of fish gelatin.

The tilapia skin presented ash content of $4.24 \mathrm{~g} / 100 \mathrm{~g}$ (wet basis; Table 1). It was an intermediary value considering those observed by Muyonga, Cole and Duodu (2004) for young $(3.7 \%)$ and adult (6.0\%) Nile perch, which, like tilapia, is a warm water fish. These authors stated that this difference is due the higher calcification of the scales according to the fish age. In the present study, fish age was not taken into account, which made impossible a comparison between the ash content and fish age.

Furthermore, the average fat content was $3.85 \mathrm{~g} / 100 \mathrm{~g}$. It is known that the peculiar smell of fish skins is due to the presence of nitrogen compounds and fats that contain high amounts of unsaturated fat acids (GROSSMAN; BERGMAN, 1992). Therefore, the treatments previous to the extraction should be performed as efficiently as possible to remove the lipid material (ALFARO et al., 2009). The average crude protein content (wet basis) found in the tilapia skin was $21.30 \%$. This value was also similar to those observed by Muyonga, Cole and Duodu (2004) for young (20.3\%) and adult (21.6\%) Nile perch specimens. It is important to highlight that the protein content present in fish skin represents the maximum amount of collagen in the animal tissue and, therefore, the maximum gelatin yield (MUYONGA; COLE; DUODU, 2004).

The average moisture content of tilapia skin gelatin was $15 \mathrm{~g} / 100 \mathrm{~g}$ (Table 1). This value is above the range reported for commercial gelatins that generally exhibit moisture content of around 9-14\%, with occasional samples out of this range (EASTOE; LEACH, 1977). As expected, the fat content was low $(0.25 \mathrm{~g} / 100 \mathrm{~g})$ and slightly higher than the values of $0.21 \%$ and $0.20 \%$ described for other fish species gelatins by Cho,

Table 1. Proximal composition of tilapia skin and tilapia skin gelatin.

\begin{tabular}{ccc}
\hline Compound $(\mathrm{g} / \mathrm{100g})$ & Tilapia skin & Tilapia skin gelatin \\
\hline Moisture & $72.6 \pm 2.49$ & $15.0 \pm 1.05$ \\
Lipids & $3.85 \pm 0.22(13.09)$ & $0.25 \pm 0.03(0.29)$ \\
Protein & $21.30 \pm 2.53(72.47)$ & $81.16 \pm 2.15(97.18)$ \\
Ash & $4.24 \pm 0.35(14.42)$ & $2.10 \pm 0.26(2.51)$ \\
\hline
\end{tabular}

Average of three independent experimental determinations \pm SD. Dry basis in parenthesis. 
Gu and Kim (2004) and Muyonga, Cole and Duodu (2004), respectively. This indicates that in the pretreatment stages the successive washings, previous to the extraction, were effective in removing tilapia skin lipids.

The ash content (wet basis) of gelatin was $2.1 \mathrm{~g} / 100 \mathrm{~g}$. This value was higher to that reported by Haug, Draget and Smidsrød (2004) for cold water fish gelatin $(0.82 \%)$. However, it was lower than the recommended maximum ash content, which is 2.6\% (JONES, 1977; MUYONGA; COLE; DUODU, 2004). Nevertheless, the ash content does not have to be considered as a limiting factor for gelatin applications, except for the fact that it indicates the maximum calcium content, which is significantly important information for some applications (JONES, 1977), such as in confectionary products.

\subsection{Minerals}

Generally, an edible gelatin must be free of heavy metals and organoleptically satisfactory (JOHNSTON-BANKS, 1990). Table 2 shows the ionic contents of 1 and $10 \mathrm{~g} / 100 \mathrm{~g}$ tilapia skin gelatin solutions. Low values of $\mathrm{Zn}^{2+}(0.6 \mathrm{mg} / \mathrm{L}), \mathrm{Mn}^{2+}$ $(0.6 \mathrm{mg} / \mathrm{L}), \mathrm{Cu}^{2+}(0.8 \mathrm{mg} / \mathrm{L})$, and $\mathrm{Fe}^{3+}(0.9 \mathrm{mg} / \mathrm{L})$ ions were observed. According to Jones (1977), high amounts of copper and iron in gelatins used in meat products may cause dark spots.

The contents of $\mathrm{Li}^{+}$and $\mathrm{K}^{+}$ions were slightly low $(1.0 \mathrm{mg} / \mathrm{L})$, as expected. However, tilapia skin gelatins had values of $\mathrm{Na}^{+}$and $\mathrm{Ca}^{2+}$ of 40.0 and $60.0 \mathrm{mg} / \mathrm{L}$, respectively. Giménez, Gómez-Guillén and Montero (2005) reported, lower $\mathrm{Na}^{+}$ion content than for $\mathrm{Ca}^{2+}$ for Dover sole skin gelatins, which are in accordance with the values found in the present study but disagree with reported by Haug, Draget and Smidsrød (2004), who found considerably higher ionic values of $\mathrm{Na}^{+}$than for $\mathrm{Ca}^{2+}$ for haddock and pollack gelatins. It is known that high calcium content must be prevented for some applications in which require the brightness of the gel since in the presence of acids it can be precipitated darkening or forming deposits in the product surface (JONES, 1977).

The results showed the low content of ions in the solution. Therefore, its ionic content does not contribute significantly to the ionic strength of fish gelatin.

\subsection{Turbidity and color}

Turbidity is the reduced transparency due the presence of material in suspension. Depending on the gelatin application, turbidity can be an important attribute (COLE, 2013; ALFARO; FONSECA; PRENTICE, 2012). The $6.67 \%(\mathrm{w} / \mathrm{v})$ gelatin solution had turbidity of $67 \pm 4.3$ NTU. Turbidity values are widely dependent on the efficiency of the clarification process (filtration) (MUYONGA; COLE; DUODU, 2004). In the present study, double filtration was carried out. The values found were slightly higher than those reported by Cole and Roberts (1997) for mammalian skin gelatins. Furthermore, high turbidity values intervene with the color determination (COLE; ROBERTS, 1996; MUYONGA; COLE; DUODU, 2004).

The tilapia skin gelatin had bright and whitish-yellow color, similar to the color of commercial gelatins, which usually varies from pale yellow to dark amber (COLE; ROBERTS, 1997; JONGJAREONRAK et al., 2010). The values for $\mathrm{L}^{*}, \mathrm{a}^{*}$, and $\mathrm{b}^{*}$ of the extracted gelatin were $89.25 \pm 11.79,-0.44 \pm 0.07$, and $2.48 \pm 0.14$, respectively.

The lightness value was similar to the those reported by Cheow and others (2007) for gelatin of Sin croaker and Shortfin scad, 91,26 and 89,33 respectively. However, the color values were considerably higher than those reported by Jongjareonrak and others (2010) for Giant catfish gelatins (20.43). Gelatin manufacture generally uses a good process to clarify the impurities of the gelatin solution, such as chemical clarification and filtration processes (BENJAKUL et al., 2009).

Similar values for redness $\left(\mathrm{a}^{*}\right)$ and yellowness $\left(\mathrm{b}^{*}\right)$ observed in the present study for wami tilapia skin gelatin were also verified for black and red tilapia skin gelatins when the same methodology was used (JAMILAH; HARVINDER, 2002). Although the color of gelatins is an important commercial attribute, there is still no universally accepted method for its measure (COLE; ROBERTS, 1997).

\subsection{Yield and $p H$}

According to Karin and Bhat (2009), the yield of gelatin extraction is on average lower than that of mammalian gelatin, which is approximately $6 \%$ and $19 \%$ (expressed as grams of dry gelatin per $100 \mathrm{~g}$ of clean skin).

The average yield of tilapia skin gelatin was $5.10 \mathrm{~g} / 100 \mathrm{~g}$, calculated according to Equation 1. This value is lower than the values reported by Jamilah and Harvinder (2002) for black and red skin gelatins (5.39\% and $7.81 \%$, respectively), but it is considerably lower than the yields reported by Grossman and Bergman (1992) for tilapia sp. gelatin (15\%) and Holzer (1996), who described a method for skin gelatin extraction that could reach yields higher than $20 \%$. The lower extraction yield of tilapia skin gelatin could be due to the loss of collagen through leaching during the series of washing steps.

Another possible explanation could be the incomplete collagen hydrolysis since low temperatures result in lower yields and incomplete extraction, while higher temperatures tend to degrade the produced gelatin affecting its quality (HOLZER, 1996; ALFARO; FONSECA; PRENTICE, 2012). However, the temperature used in the present study, during the extraction

Table 2. Ionic contents of tilapia skin gelatin solutions.

\begin{tabular}{ccccccccc}
\hline Concentration $(\mathrm{mg} / \mathrm{L})$ & $\mathrm{Na}^{+}$ & $\mathrm{K}^{+}$ & $\mathrm{Ca}^{2+}$ & $\mathrm{Li}^{+}$ & $\mathrm{Fe}^{3+}$ & $\mathrm{Cu}^{2+}$ & $\mathrm{Zn}^{2+}$ & $\mathrm{Mn}^{2+}$ \\
\hline $10 \%(\mathrm{w} / \mathrm{v})$ & $42 \pm 2.0$ & $\mathrm{NM}$ & $48 \pm 3.0$ & $\mathrm{NM}$ & $\mathrm{NM}$ & $\mathrm{NM}$ & $\mathrm{NM}$ & $\mathrm{NM}$ \\
$1 \%(\mathrm{w} / \mathrm{v})$ & $40 \pm 1.0$ & 1.00 .1 & $60 \pm 4.0$ & $1.0 \pm 0.2$ & $0.9 \pm 0.3$ & $0.8 \pm 0.1$ & $0.6 \pm 0.1$ & $0.6 \pm 0.1$ \\
\hline
\end{tabular}

Average of three independent experimental determinations \pm SD. NM $=$ non measured. 
stage, was similar to that previously used in other studies, indicating that the lower yield is probably due the excessive loss of collagen during the previous washing stages.

The average $\mathrm{pH}$ value determined for tilapia skin gelatin was $4.66 \pm 0.41$. It is higher than the values found by Jamilah and Harvinder (2002) for black and red tilapia skin gelatins, 3.81 and 3.05 , respectively. The $\mathrm{pH}$ found is considerably higher than previously reported values; however, it is within the range described for gelatins solubilized with acid, which is between 3.8 and 5.0 (JONES, 1977). The $\mathrm{pH}$ of a gelatin solution is affected by the chemical treatment used during the extraction (GUDMUNDSSON; HAFSTEINSSON, 1997). Therefore, higher natural $\mathrm{pH}$ of the tilapia skin gelatin is possibly due to the efficiency of the washing stages subsequent to the chemical treatments during skin preparation, before the extraction stage.

\section{Conclusions}

The average protein content (wet basis) found in the tilapia skin was $21.30 \%$, which indicates a potential source of fish gelatin production. The extraction yield of tilapia skin gelatin was lower, probably due the loss of collagen through leaching during the series of washing steps. The gelatin had bright and whitish-yellow color, with $\mathrm{L}^{\star}$, $\mathrm{a}^{*}$ and $\mathrm{b}^{\star}$ values of $89.25,-0.44$, and 2.48 , respectively. The results obtained in the present study indicated the possibility of using tilapia skin for gelatin production.

\section{Acknowledgements}

The researchers would like to thank the Research Support Program of the Federal Technological University of Paraná (UTFPR) - Campus Francisco Beltrão.

\section{References}

ALFARO, A. T. et al. Effect of extraction parameters on the properties of gelatin from King weakfish (Macrodon ancylodon) bones. Food Science and Technology International, v. 15, p. 553-562, 2009. http://dx.doi.org/10.1177/1082013209352921

ALFARO, A. T.; FONSECA, G. G.; PRENTICE, C. Enhancement of functional properties of wami tilapia (Oreochromis urolepis hornorum) skin gelatin at different $\mathrm{pH}$ values. Food and Bioprocess Technology, v. 5, p. 1-10, 2012.

ASSOCIATION OF OFFICIAL ANALYTICAL CHEMISTS - AOAC. Official Methods of the Association of Official Agricultural Chemist's International. 17th ed. Gaithersburg: AOAC International, 2000.

BENJAKUL, S. et al. Characteristics of gelatin from the skins of bigeye snapper, Priacanthus tayenus and Priacanthus macracanthus. Food Chemistry, v. 116, n. 2, p. 445-451, 2009. http://dx.doi. org/10.1016/j.foodchem.2009.02.063

BRITISH STANDARDS INSTITUTION - BSI. Methods for Sampling and Testing Gelatin (Physical and Chemical Methods). London: British Standards Institution, 1975.

CHEOW, C. S. et al. Preparation and characterisation of gelatins from the skins of sin croaker (Johnius dussumien) and shortfin scad (Decapterus macrosoma). Food Chemistry, v. 101, p. 386-391, 2007. http://dx.doi.org/10.1016/j.foodchem.2006.01.046
CHO, S. M.; GU, Y. S.; KIM, S. B. Extracting optimization and physical properties of yellowfin tuna (Thunnus albacares) skin gelatin compared to mammalian gelatins. Food Hydrocolloids, v. 19, p. 221-229, 2004. http://dx.doi.org/10.1016/j.foodhyd.2004.05.005

COLE, C. G. B. Gelatin Food Science. 2013. Disponível em: <http:// www.gelatin.co.za>. Acesso em: 03 jul. 2013.

COLE, C. G. B.; ROBERTS, J. J. Gelatine colour measurement. Meat Science, v. 45, p. 23-31, 1997. http://dx.doi.org/10.1016/S03091740(96)00096-4

COLE, C. G. B.; ROBERTS, J. J. Changes in the molecular composition of gelatin due to the manufacturing process and animal age, as shown by electrophoresis. Journal of the Society of Leather Technologies and Chemists, v. 80, p. 136-141, 1996.

EASTOE, J. E.; LEACH, A. A. Chemical constitution of gelatin. In: WARD, A. G.; COURTS, A. (Ed.). The Science and Technology of Gelatin. London: Academic Press, 1977. p. 73-108.

GIMÉNEZ, B.; GÓMEZ-GUILLÉN, M. C.; MONTERO, P. The role of salt washing of fish skins in chemical and rheological properties of gelatin extracted. Food Hydrocolloids, v. 19, p. 951-957, 2005. http://dx.doi.org/10.1016/j.foodhyd.2004.09.012

GÓMEZ-GUILLÉN, M. C. et al. Functional and bioactive properties of collagen and gelatin from alternative sources: A review. Food Hydrocolloids, v. 25, p. 1813-1827, 2011. http://dx.doi. org/10.1016/j.foodhyd.2011.02.007

GROSSMAN, S.; BERGMAN, M. Process for the production of gelatin from fish skins. US Patent 5.093.474, 1992.

GUDMUNDSSON, M.; HAFSTEINSSON, H. Gelatin from cod skins as affected by chemical treatments. Journal of Food Science, v. 62, p. 37-39, 1997. http://dx.doi.org/10.1111/j.1365-2621.1997. tb04363.x

HAUG, I. J.; DRAGET, K. I.; SMIDSRØD, O. Physical and rheological properties of fish gelatin compared to mammalian gelatin. Food Hydrocolloids, v. 18, p. 203-213, 2004. http://dx.doi.org/10.1016/ S0268-005X(03)00065-1

HOLZER, D. Gelatin production. US Patent 5.484.888, 1996.

JAMILAH, B.; HARVINDER, KG. Properties of gelatins from skins of fish: black tilapia (Oreochromis mossambicus) and red tilapia (Oreochromis nilotica). Food Chemistry, v. 77, p. 81-84, 2002. http:// dx.doi.org/10.1016/S0308-8146(01)00328-4

JOHNS, P.; COURTS, A. Relationship between collagen and gelatin. In: WARD, A. G.; COURTS, A. (Ed.). The Science and Technology of Gelatin. London: Academic Press, 1977. p. 138-177.

JOHNSTON-BANKS, F. A. Gelatin: Food gels. Food Science Series. New York: Elsevier Applied, 1990. p. 233-289.

JONES, N. R. Uses of gelatin in edible products. In: WARD, A. G.; COURTS, A. (Ed.). The Science and Technology of Gelatin. London: Academic Press; 1977. p. 365-394. PMid:15044.

JONGJAREONRAK, A. et al. Chemical compositions and characterisation of skin gelatin from farmed giant catfish (Pangasianodon gigas). LWT- Food Science and Technology, v. 43, p. 161-165, 2010.

KARIN, A. A.; BHAT, R. Fish gelatin: properties, challenges, and prospects as an alternative to mammalian gelatins. Food Hydrocolloids, v. 23, p. 563-576, 2009. http://dx.doi.org/10.1016/j. foodhyd.2008.07.002

LEACH, A. A.; EASTOE, J. E. The chemical examination of gelatins. In: WARD, A. G.; COURTS, A. (Ed.). The Science and Technology of Gelatin. London: Academic Press; 1977. p. 365-394.

MUYONGA, J. H.; COLE, C. G. B.; DUODU, K. G. Extraction and physico-chemical characterisation of Nile perch (Lates niloticus) skin and bone gelatin. Food Hydrocolloids, v. 18, p. 581-592, 2004. http://dx.doi.org/10.1016/j.foodhyd.2003.08.009 